DOI https://doi.org/10.36059/978-966-397-159-9/52-68

\title{
CRIMINAL PROCEEDINGS REGARDING ENFORCED DISAPEARANCE IN UKRAINE: ISSUES OF NORMATIVE REGULATION
}

\section{Iryna Hloviuk}

\section{INTRODUCTION}

International Convention for the Protection of All Persons from Enforced Disappearance of adopted on 20 December 2006 (Convention) came into effect in Ukraine on 13 September 2015. Under Convention, no one shall be subjected to enforced disappearance. No exceptional circumstances whatsoever, whether a state of war or a threat of war, internal political instability or any other public emergency, may be invoked as a justification for enforced disappearance. For the purposes of this Convention, «enforced disappearance» is considered to be the arrest, detention, abduction or any other form of deprivation of liberty by agents of the State or by persons or groups of persons acting with the authorization, support or acquiescence of the State, followed by a refusal to acknowledge the deprivation of liberty or by concealment of the fate or whereabouts of the disappeared person, which place such a person outside the protection of the law.

Convention also prescribes a number of procedural rules which should be considered in the course of criminal proceedings regarding offence of enforced disappearance (particularly, Articles 3, 8, 10, 11, 12, 14, 17, 24 etc.). Despite the significance of these aspects for contemporary lawenforcement practice, there are no special studies in Ukraine on issues of criminal proceedings regarding enforced disappearance. That is why the goal of the research is to identify issues of ensuring the provisions of Convention by procedural means of domestic legislation.

\section{Issues of pre-trial investigation and placement in public or private custodial settings}

Enforced disappearance is an offence of public prosecution so information shall be entered in the Integrated Register of Pre-Trial Investigations (IRPI), and pre-trial investigation shall be instituted without a victim's application. 
Thorough and impartial investigation as a requirement of Convention suggests that the investigation shall be effective, that is, to meet the criteria established by the case-law of European Court of Human Rights (ECtHR), in particular for cases of enforced disappearance involving deprivation of life. Since all international human rights agencies recognize the state's obligation to account for a detainee's fate. Considering the difficulties of proving the State's involvement in certain cases of enforcement disappearance characterized by unlawful detention, it is the state's responsibility to account for the disappeared persons fate. In that regard, the state may be found responsible for violation of right to life in cases when the body of the missing person was not found. After a brief hesitation ECtHR joined the practice of United Nations Human Rights Committee and Inter-American Court of Human Rights and acknowledged the presumption of facts and shifts of burden of proof onto the state for the cases of disappearances when victims were last seen in places under the Government's control, in the absence of direct evidence that persons concerned were not detained (Imakayeva v. Russia, para. 115, Tanis v. Turkey, para. 160, 206-210; Varnava and others v. Turkey, para. 181-186). Government's inability to provide satisfactory and convincing explanation as to what happened to the disappeared persons, together with the presumption of their death, could also result in a violation of right to life by the Government ${ }^{1}$. For instance, in case of 'Imakayeva v. Russia', ECtHR stated that where the events in issue lie wholly, or in large part, within the exclusive knowledge of the authorities, such as in cases where persons are under their control in custody, strong presumptions of fact will arise in respect of injuries and death occurring during that detention. Indeed, the burden of proof may be regarded as resting on the authorities to provide a satisfactory and convincing explanation. These principles apply also to cases in which, although it has not been proved that a person has been taken into custody by the authorities, it is possible to establish that he or she entered a place under their control and has not been seen since that time. In such circumstances, the onus is on the Government to provide a plausible explanation as to what happened on the premises and to show that the person concerned was not detained by the authorities, but left the premises without subsequently being deprived of his or her liberty (paras. 114, 115). The Court has also found in many cases concerning disappearances that a missing person may be presumed dead.

\footnotetext{
${ }^{1}$ Khrystova H. Pro pozytyvni zoboviazannia derzhavy stosovno prav liudyny v umovakh zbroinoho konfliktu ta yoho naslidkiv [On positive obligations of the state regarding human rights in conditions of armed conflict and its consequences]. Retrieved from https://rm.coe.int/native/168072b3cf (accessed 16 October 2019).
} 
The Court has made findings of presumptions of deaths in the absence of any reliable news about the disappeared persons for periods ranging from four years to more than ten years ('Sultygov and others v. Russia', paras. $395,396)$.

The offence provided for by Article 146-1 Para. 1 of Criminal Code of Ukraine (CC of Ukraine) is subject to the jurisdiction of the investigative bodies of the National police, except for cases when it is subject to jurisdiction of the investigative bodies of State Bureau of Investigation under rules of personal jurisdiction. As argued by $\mathrm{B}$. Babin ${ }^{2}$ the fact that the offence provided for by Article 146-1 of CC of Ukraine is subject to jurisdiction of the National police is quite controversial. Considering that allegations of enforced disappearance in Ukraine are usually made against the officials of Security Service of Ukraine, military service and the National police itself (as well as disappearances made by agents of the countryaggressor) it is too optimistic to expect the effectiveness from investigators of the National police.

The offence provided for by Article 146-1 Para. 1 of CC of Ukraine is an offence of medium gravity, thus no covert investigative (detective) actions could be conducted in course of criminal proceedings save for collecting information from electronic information systems or parts thereof the access to which is not restricted by the system's owner, possessor or keeper or is not related to circumventing a system of logical protection and establishing the location of a radio electronic device. As regards the offence provided for by Article 146-1 Para. 2 of CC of Ukraine that is a grave crime, there is no limitations as to conduct of covert investigative (detective) actions. However, it should be noted that, even in exceptional cases related to preventing the commission of crime provided for by Article 146-1 Para. 1 of $\mathrm{CC}$ of Ukraine, there is no possibility to conduct covert investigative (detective) actions (i.e., establishing the location of a radio electronic device (Article 268 Para. 4 of Code of Criminal Procedure of Ukraine (CCP of Ukraine); surveillance of an individual (Article 269 Para. 3)) as Article 250 of CCP of Ukraine allows such procedure only in case of prevention of commission of grave crimes or crimes of exceptional gravity that are set out in Chapters I, II, VI, VII (Articles 201 and 209), IX, XIII, XIV, XV, XVII of Special Part of CC of Ukraine, which is inappropriate considering the specifics of the offence provided for by Article 146-1 Para. 2 of CC of

\footnotetext{
${ }^{2}$ Babin B. (2019, February 24) Nasylnytski znyknennia v Ukraini. Pravovi deklaratsii ta realii viiny [Enforced disappearances in Ukraine. Legal declarations and realities of war]. Ukrainska Pravda. Retrieved from https://www.pravda.com.ua/columns/2019/02/24/7207525/ (accessed 16 October 2019).
} 
Ukraine as well as victim's vulnerability and difficulties connected to their protection.

Certain questions arise regarding the access to public or private custodial settings. According to Convention every State party shall ensure that the authorities referred to in paragraph 1 of this article (i.e., conducting investigation): $b$ ) have access, if necessary with the prior authorization of a judicial authority, which shall rule promptly on the matter, to any place of detention or any other place where there are reasonable grounds to believe that the disappeared person may be present. However, the provisions of current legislation are not completely in compliance with that rule. For instance, Law of Ukraine 'On pre-trial detention' provides that the administration of place of pre-trial detention is obliged to: create necessary working conditions for an investigator, a prosecutor, an investigative judge and court, which is connected to criminal proceedings (Article 21). Internal regulations of a detention center of State Penitentiary Service of Ukraine, approved by Ministry of Justice of Ukraine of 14 June 2019, provide that prosecutor conducting supervision has a right to enter pre-trial detention centers ('SIZO') at any time. Upon an investigator's, prosecutor's or investigative judge's decision, written order to conduct criminal proceedings, medical forensic analysis in the territory of a pre-trial detention centers the administration is required to: provide premises; transfer of a detainee, convicted person to the requested premise and provide protection to them; ensure the access of persons involved in investigative actions to pre-trial detention centers. Law of Ukraine "On Prosecutor's Office" provides that a prosecutor while supervising the compliance with law during the execution of court decisions in criminal cases as well as during application of other coercive measures involving restriction of persons' freedoms, has a right, upon the presentation of a document certifying his or her position to enter at any time detention places, centers, pre-trial detention facilities, where persons serve their sentences, facilities where people are placed awaiting for application of compulsory medical or educational measures, and any other places to which persons where carried in order to draw up an administrative offence report or where persons are detained upon court or administrative body decision. Nonetheless, para. 10-1 of Order "On organization of prosecutor's activity of supervising the compliance with law during the execution of court decisions in criminal cases as well as during application of other coercive measures involving restriction of persons' freedoms" of 20 April 2016 obliges a prosecutor to immediately release illegally detained person (in case of absence of relevant court decision, decision of administrative body or other document prescribed by law or after 
the time limit prescribe by law or the decision has expired) kept in detention places, centers, pre-trial detention facilities, facilities where the coercive measure are applied, other places to which persons where carried in order to draw up an administrative offence report or where persons are detained upon court or administrative body decision.

However, despite these rules neither an investigator, or prosecutor who provides procedural guidance has any rights that would demonstrate that they have access 'to any other place where there are reasonable grounds to believe that the disappeared person may be present' as stated in Convention. The quoted provisions of legal acts of Ukraine fail to take into account situations of enforced disappearance.

Article 17 of Convention provides that no one shall be held in secret detention. Without prejudice to other international obligations of the State Party with regard to the deprivation of liberty, each State Party shall, in its legislation: a) establish the conditions under which orders of deprivation of liberty may be given; b) indicate those authorities authorized to order the deprivation of liberty; c) guarantee that any person deprived of liberty shall be held solely in officially recognized and supervised places of deprivation of liberty; d) guarantee that any person deprived of liberty shall be authorized to communicate with and be visited by his or her family, counsel or any other person of his or her choice, subject only to the conditions established by law, or, if he or she is a foreigner, to communicate with his or her consular authorities, in accordance with applicable international law; e) guarantee access by the competent and legally authorized authorities and institutions to the places where persons are deprived of liberty, if necessary with prior authorization from a judicial authority; f) guarantee that any person deprived of liberty or, in the case of a suspected enforced disappearance, since the person deprived of liberty is not able to exercise this right, any persons with a legitimate interest, such as relatives of the person deprived of liberty, their representatives or their counsel, shall, in all circumstances, be entitled to take proceedings before a court, in order that the court may decide without delay on the lawfulness of the deprivation of liberty and order the person's release if such deprivation of liberty is not lawful. In case of enforced disappearance, the domestic criminal procedural law has the mechanism provided for by Article 206 of CCP of Ukraine. Despite the fact that the article is in Chapter 18 - preventive measure, apprehension of a person, the content of the article, particularly the provision that each investigating judge whose territorial jurisdiction extends to a person committed to custody may issue a ruling by which orders any public authority or official to ensure respect for such person's right; whenever an 
investigating judge receives information from any sources whatsoever, which gives ground for a reasonable suspicion that within the court's territorial jurisdiction, there is a person who has been deprived of liberty without valid court's decision, or has not been released from custody after the payment of bail in accordance with the procedure laid down in the present Code, such judge is required to issue a ruling by which orders any public authority or official in whose custody the person is kept, to immediately bring this person to the investigating judge in view of verifying grounds for deprivation of liberty, - indicates that these rules can also be applied in case of enforced disappearance of a person that were placed in public or private custodial settings.

Within the context of application of appropriate measures to ensure the protection of a complainant, witnesses, relatives of the disappeared person and their defence counsel, as well as persons participating in the investigation as provided for by Article 12 of Convention, the following may be pointed out. CCP of Ukraine does not have the chapter dedicated to measures to ensure the safety. Instead, there is Law of Ukraine 'On ensuring the safety of persons participating in criminal proceedings' of 23 December 1993 that has the list of measures to ensure safety of persons which have a right to safety, bodies that ensure the safety, the procedure of initiation of adopting a decision on application of measure to ensure the safety and etc. Certain provisions of CCP of Ukraine, in particular regarding using video conference (Articles 232 and 336 of CCP of Ukraine), interrogation from another premise (Article 352 of CCP of Ukraine), also have the legal nature of measure to ensure the safety.

Article 10 of Convention provides that any State party in whose territory a person suspected of having committed an offence of enforced disappearance is present shall take him or her into custody or take such other legal measures as are necessary to ensure his or her presence. The custody and other legal measures shall be as provided for in the law of that State Party but may be maintained only for such time as is necessary to ensure the person's presence during criminal procedural actions. However, such wording is contrary to the presumption of achieving the aim - effectiveness of criminal proceedings - without application of measures to ensure criminal proceedings $^{3}$, among which is a custody as a preventive measure, as well as

\footnotetext{
${ }^{3}$ Hloviuk I. V. (2013) Prezumptsii y tiahar dokazuvannia u rozghliadi slidchym suddeiu klopotan pro zastosuvannia zakhodiv zabezpechennia kryminalnoho provadzhennia [Presumptions and burden of proof in considering motions on application of measures to ensure criminal proceedings by an investigative judge]. Yurydychnyi chasopys Yurydychnyi chasopys Natsionalnoi akademii vnutrishnikh sprav [Legal herald of National academy of internal affairs], no. 2, pp. 84-89.
} 
presumption of a person's freedom when applying Article 5 (c) of the Convention for the Protection of Human Rights and Fundamental Freedom $(\text { ECHR })^{4}$.

It should be noted that regarding enforced disappearance application of mechanisms provided for by Law of Ukraine 'On legal status of missing persons'. A missing person is an individual whose whereabouts are unknown at the time of submission of an application for a search by an applicant (Article 1 of the Law). The person is regarded missing from either the moment of the application on the fact of missing a person and his/her search was filed or upon court decision (Article 4 of the Law).

Article 5 of Law of Ukraine 'On legal status of missing persons' provides that the missing person has all the rights guaranteed by the Constitution of Ukraine as well as the right to comprehensive investigation into circumstances surrounding the missing person and clarification on his/her whereabouts. In fact, it is the reference to effective investigation, criteria of which were formulated by ECtHR in regard to Article 2 of ECHR. It is noteworthy that regarding a disappearance ECtHR stated that it is a distinct phenomenon, characterised by an ongoing situation of uncertainty and unaccountability in which there is a lack of information or even a deliberate concealment and obfuscation of what has occurred. This situation is very often drawn out over time, prolonging the torment of the victim's relatives. Thus, the procedural obligation will, potentially, persist as long as the fate of the person is unaccounted for; the ongoing failure to provide the requisite investigation will be regarded as a continuing violation. This is so, even where death may, eventually, be presumed (see cases of 'Varnava and Others v. Turkey', § 148 and 'Aslakhanova and Others v. Russia', § 122).

According to Article 2 of ECHR, the essential purpose of effective investigation is to secure the effective implementation of the domestic laws which protect the right to life. The form of investigation that will achieve this purpose may vary in different circumstances. However, whatever mode is employed, the authorities must act of their own motion once the matter has come to their attention. They cannot leave it to the initiative of the next of kin either to lodge a formal complaint or to take responsibility for the

${ }^{4}$ Zavtur V. A. (2018) Prezumptsiia svobody osoby pry zastosuvanni punktu «S» statti 5 Konventsii pro zakhyst prav liudyny i osnovopolozhnykh svobod: praktyka Yevropeiskoho sudu z prav liudyny i natsionalnyi kontekst [Presumption of a person's freedom in application of Article 5 (c) of Convention for the Protection of Human Rights and Fundamental Freedom: case-law of European Court of Human Rights and domestic context]. Proceedings of the Praktyka Yevropeiskoho sudu z prav liudyny v diialnosti orhaniv prokuratury i sudu: vyklyky ta perspektyvy : mater. I Mizhnar. nauk.-prakt. konf. (Ukraine, Kyiv, June 13, 2018), Kyiv: National Prosecution Academy of Ukraine, pp.81-85. 
conduct of any investigatory procedure (see case of 'Muravskaya v. Ukraine', § 41). Thus, regarding a disappearance the state has an obligation to react to the fact regardless of whether a complaint has been lodged. Article 18 of the Law of Ukraine 'On legal status of missing persons' stipulates that an application for a search for a missing person shall be lodged to the appropriate local agency of the National police of Ukraine. The application for a search for a missing person may be lodged by a relative, a representative of a military formation, public authority, local government, citizen's association or any other person has learned about the fact of missing. The application may be lodged by the Commission on Missing Persons in Special Circumstances if persons provided in paragraph two of the current part applied to the commission with the notification on a missing person. Which raises several issues. First, the only legal fact provided by law to search a missing person is an application which raises a question whether it is possible to initiate the search by the National police when information about the missing persons was received from other sources. The answer must be positive as it stems from positive obligations of the state under Article 2 of ECHR, however it is not directly stipulated in the Law of Ukraine 'On legal status of missing persons'. Besides that, the person in question obtains the status of a missing person from the moment of the application on the fact of missing a person and his/her search was filed or upon the court's decision. These provisions, again, actualize the issue of ex officio authority for carrying out the search.

Secondly, the Law of Ukraine 'On legal status of missing persons' refers to submission of an application 'to the appropriate local agency of the National police of Ukraine', however how the 'appropriateness' of local agency of the National police of Ukraine should be addressed (depending on the place of disappearance, the last place of that person's place of residence or whereabouts, place of residence of his/her relatives, location of a military formation, location of public authority or local government, location of the Commission on Missing Persons in Special Circumstances etc.) is missing in the law. Effective investigation should not have such formal limitations, thus it more logical to stipulate that the application may be lodged to any local agency of the National police of Ukraine ${ }^{5}$.

${ }^{5}$ Hloviuk I. V. (2019) Rozsliduvannia faktiv znyknennia bezvisty (u konteksti torhivli liudmy) [Investigation of facts of disappearance (within the context of human trafficking)]. Proceedings of the Protydiia nezakonnii mihratsii ta torhivli liudmy: materialy III Mizhnarodnoho naukovo-praktychnoho sympoziumu (Ukraine, Ivano-Frankivsk, April 12-13, 2019), Ivano-Frankivsk: Editorial and Publishing Department of King Danylo University, pp.31-34. 


\section{Issues of court proceedings and compensation for damage}

Recommendation No. R (97) 13 of the Committee of Ministers of the Council of Europe to Member States concerning intimidation of witnesses and the rights of the defence provides that while respecting the rights of the defence, witnesses should be provided with alternative methods of giving evidence which protect them from intimidation resulting from face to face confrontation with the accused, for example by allowing witnesses to give evidence in a separate room. The following measures should, inter alia, be considered: recording by audiovisual means statements made by witnesses during pre-trial examination; using pre-trial statements given before a judicial authority as evidence in court when it is not possible for witnesses to appear before the court or when appearing in court might result in great and actual danger to the life and security of witnesses, their relatives or other persons close to them; revealing the identity of witnesses at the latest possible stage of the proceedings and/or releasing only selected details; excluding the media and/or the public from all or part of the trial. Is should be noted that not all of these recommendations can be realized under current $\mathrm{CCP}$ of Ukraine, including the proceedings regarding enforced disappearance. Recorded by audiovisual means statements made by witnesses during pre-trial examination can be used, however according to Articles 23 and 95 of CCP of Ukraine the recording cannot be deemed as a testimony for a court and be used when delivering a judgement. Use of testimonies, given to a court during pre-trial investigation, is possible in court if appearing of witnesses in a court is impossible or when appearing in a court might result in great and actual danger to the life and security of witnesses, their relatives or other persons close to them, in case of deposition of evidence is admissible, however when filing a motion to an investigative judge pursuant to Article 225 of CCP of Ukraine an investigator should indicate what circumstances demonstrate the existence of danger to witnesses' or victims' life and health. Nonetheless, in case of deposition of evidence the court has a right to question the victim, the witness that were questioned according to the rules of the current article, for instance in case the interrogation was conducted in the absence of the defence party or where there is a need to clarify testimonies or take testimonies regarding any circumstances that were not clarified as a result of interrogations in the course of pre-trial investigation (Article 225 Para. 4); considering these provisions the court may make the decision proprio motu.

As regards interrogation in a court, considering the sensitive nature of the issue of victims' and witnesses' questioning in the proceedings, it should be noted that it is difficult to model proposals on amendments to criminal 
procedural legislation regarding the victim's and the witness's possibility not to testify in court, but to use deposited testimonies or testimonies recorded in video or audio. This is because everyone charged with a criminal offence has a right to examine or have examined witnesses against him and to obtain the attendance and examination of witnesses on his behalf under the same conditions as witnesses against him (Article 6 of ECHR), and the notion of a witness has an autonomous meaning in the case-law of ECtHR and applies to a victim. Although, ECtHR does not object to the possibility of using testimony of an absent witness, however, it imposes certain limitations. For instance, in case of 'Al-Khawaja and Tahery v. the United Kingdom' ECHR has formulated the test to decide whether there was a violation of the Article $6 \S \S 1$ and 3 (d) of ECHR. Article $6 \S 1$ of ECHR together with Article $6 \S 3$ (d) of ECHR enshrines a principle that, before an accused can be convicted, all evidence against him must normally be produced in his presence at a public hearing with a view to adversarial argument. Exceptions to this principle are possible but must not infringe the rights of the defence, which, as a rule, require that the accused should be given an adequate and proper opportunity to challenge and question a witness against him, either when that witness makes his statement or at a later stage of proceedings. There are two requirements which follow from the above general principle. Firstly, there must be a good reason for the non-attendance of a witness. The death or a witness's non-attendance due to the fear, whereas the accused person or those acting on his/her behalf are accountable for that, is regarded as good reasons as in the latter case the accused person is deemed as one who waived his/her rights guaranteed by Article $6 \S 3$ (d). Before a witness can be excused from testifying on grounds of fear, the trial court must be satisfied that all available alternatives, such as witness anonymity and other special measures, would be inappropriate or impracticable. Secondly, when a conviction is based solely or to a decisive degree on depositions that have been made by a person whom the accused has had no opportunity to examine or to have examined, whether during the investigation or at the trial, the rights of the defence may be restricted to an extent that is incompatible with the guarantees provided by Article 6 (the so-called "sole or decisive rule"). However, the rule is not absolute and cannot be applied in an inflexible manner while ignoring entirely the specificities of the particular legal system concerned as it would transform the rule into a blunt and indiscriminate instrument that runs counter to the traditional way in which ECtHR approaches the issue of the overall fairness of the proceedings, namely to weigh in the balance the competing interests of the defence, the victim, and witnesses, and the public interest in the effective administration 
of justice. Therefore, where a hearsay statement is the sole or decisive evidence against a defendant, its admission as evidence will not automatically result in a breach of Article $6 \S 1$ of ECHR. At the same time, where a conviction is based solely or decisively on the evidence of absent witnesses, ECtHR must subject the proceedings to the most searching scrutiny. Because of the dangers of the admission of such evidence, it would require sufficient counterbalancing factors, including the existence of strong procedural safeguards. As to the question whether these guarantees were applied in practice, ECHR has considered three issues in each case: whether it was necessary to admit the witness statements of absent witnesses; whether their untested evidence was the sole or decisive basis for each applicant's conviction; whether there were sufficient counterbalancing factors including strong procedural safeguards to ensure that each trial, judged as a whole, was fair ${ }^{6}$.

Consequently, while applying relevant rules of CCP of Ukraine, particularly regarding court's questioning of victims, once the deposition of testimonies has been used, re-examination of victims, witnesses, examination of victims, witnesses that are subject to measures of security, so that the overall fairness of trial and legality of court decision would not be questioned later the mode of video conference should be used, to interrogate victims, witnesses using technical means from other premises, including outside the premises of court, or in other way making his identification impossible, and ensures parties to criminal proceedings the possibility to ask questions and hear answers thereto in conditions making his identification impossible. Article 352 Para. 9 of CCP of Ukraine provides that before such ruling is made the court shall be required to establish whether the parties to criminal proceedings have any objections to the examination of a witness in the conditions making his identification impossible and, if found founded, decline to have the witness examined under the rules of this paragraph. While making a ruling the court has an obligation to consider legal positions laid down by ECHR, inter alia, in cases of 'Al-Khawaja and Tahery v. the United Kingdom', 'Schatschaschwili v. Germany', 'Boyets v. Ukraine', 'Murtazaliyeva v. Russia'. For example, the Court reiterates that the guarantees in paragraph 3 (d) of Article 6 are specific aspects of the right to a fair hearing set forth in paragraph 1 of this provision which must be taken into account in any assessment of the fairness of proceedings. According to

6 Drozdov O., Drozdova O. (2016) Ohliad sprav shchodo inozemnykh krain, rozghlianutykh YeSPL protiahom bereznia 2016 roku [Review of the cases regarding foreign states decided by ECtHR during March 2016]. Visnyk Natsionalnoi asotsiatsii advokativ Ukrainy [Herald of Ukrainian Bar Association], vol. 24, no. 6, pp. 46-48. 
the Court's case-law, the use in evidence of statements obtained at the police inquiry and judicial investigation stages is not in itself inconsistent with the provisions cited above, provided that the rights of the defence have been respected. In principle, these rules require that the defendant be given an adequate and proper opportunity to challenge and question a witness against him, either when he makes his statements or at a later stage of proceedings. In Al-Khawaja and Tahery, the Grand Chamber clarified the principles to be applied when a witness does not attend a public trial. Those principles may be summarised as follows: (i) the Court should first examine the preliminary question of whether there was a good reason for admitting the evidence of an absent witness, keeping in mind that witnesses should as a general rule give evidence during the trial and that all reasonable efforts should be made to secure their attendance; (ii) typical reasons for non-attendance are, as in the case of Al-Khawaja and Tahery, the death of the witness or the fear of retaliation. There are, however, other legitimate reasons why a witness may not attend a trial; (iii) when a witness has not been examined at any prior stage of the proceedings, allowing the admission of a witness statement in lieu of live evidence at trial must be a measure of last resort; (iv) the admission as evidence of the statements of absent witnesses results in a potential disadvantage for the defendant, who, in principle, in a criminal trial should have an effective opportunity to challenge the evidence against him. In particular, he should be able to test the truthfulness and reliability of the evidence given by the witnesses, by having them orally examined in his presence, either at the time the witness was making the statement or at some later stage of the proceedings; (v) according to the "sole or decisive rule", if the conviction of a defendant is solely or mainly based on evidence provided by witnesses whom the accused is unable to question at any stage of the proceedings, his defence rights are unduly restricted; (vi) in this context, the word "decisive" should be narrowly understood as indicating evidence of such significance or importance as is likely to be determinative of the outcome of the case. Where the untested evidence of a witness is supported by other corroborative evidence, the assessment of whether it is decisive will depend on the strength of the supportive evidence: the stronger the other incriminating evidence, the less likely that the evidence of the absent witness will be treated as decisive; (vii) however, as Article $6 \S 3$ of the Convention should be interpreted in the context of an overall examination of the fairness of the proceedings, the sole or decisive rule should not be applied in an inflexible manner; (viii) in particular, where a hearsay statement is the sole or decisive evidence against a defendant, its admission as evidence will not automatically result in a breach of Article $6 \S 1$. At the same time, where a 
conviction is based solely or decisively on the evidence of absent witnesses, the Court must subject the proceedings to the most searching scrutiny. Because of the dangers of the admission of such evidence, it would constitute a very important factor to balance in the scales and one which would require sufficient counterbalancing factors, including the existence of strong procedural safeguards. The question in each case is whether there are sufficient counterbalancing factors in place, including measures that permit a fair and proper assessment of the reliability of that evidence to take place. This would permit a conviction to be based on such evidence only if it is sufficiently reliable given its importance to the case. Those principles have been further clarified in the case of Schatschaschwili v. Germany ([GC], no. 9154/10, §§ 110-31, ECHR 2015) in which the Grand Chamber confirmed that the absence of good reason for the non-attendance of a witness could not, of itself, be conclusive of the lack of fairness of a trial, although it remained a very important factor to be weighed in the balance when assessing the overall fairness, and one which might tip the balance in favour of finding a breach of Article $6 \S \S 1$ and 3 (d). Furthermore, given that its concern was to ascertain whether the proceedings as a whole were fair, the Court should not only review the existence of sufficient counterbalancing factors in cases where the evidence of the absent witness was the sole or the decisive basis for the applicant's conviction, but also in cases where it found it unclear whether the evidence in question was sole or decisive but nevertheless was satisfied that it carried significant weight and its admission might have handicapped the defence. The extent of the counterbalancing factors necessary in order for a trial to be considered fair would depend on the weight of the evidence of the absent witness. The more important that evidence, the more weight the counterbalancing factors would have to carry in order for the proceedings as a whole to be considered fair ('Boyets v. Ukraine', paras. 74-76).

At the same time, consideration should be given to one more issue of the procedure of examination of a witness with the use of technical means from another premise, including outside court's building, or in other way making his identification impossible, and ensures parties to criminal proceedings the possibility to ask questions and hear answers thereto. Article 352 Para. 9 of $\mathrm{CCP}$ of Ukraine provides the following: In exceptional cases with a view to ensure security of a witness to be examined, the court, proprio motu or upon the motion of parties to criminal proceedings or of the witness himself, passes a reasoned ruling to examine the witness concerned with the use of technical means from another premise, including outside court's building, or in other way making his identification impossible, and ensures parties to 
criminal proceedings the possibility to ask questions and hear answers thereto. If there is a danger that witness's voice can be identified, examination may be accompanied by acoustic disturbance. Before such ruling is made the court shall be required to establish whether the parties to criminal proceedings have any objections to the examination of a witness in the conditions making his identification impossible and, if found founded, decline to have the witness examined under the rules of this paragraph. However, these rules cannot be applied if no security measure were taken to the witness or the victim within criminal proceedings under Law of Ukraine 'On ensuring the safety of persons participating in criminal proceedings'. Additionally, questioning under Article 352 Para. 9 of CCP of Ukraine indicates that the procedure can be used solely for preventing witness's, victim's identification; thus, if the witness or the victim are identified the procedure cannot be used.

According to Article 24 of Convention, each State party shall ensure in its legal system that the victims of enforced disappearance have the right to obtain reparation and prompt, fair and adequate compensation. Article 1177 of Civil Code of Ukraine provides that the damage caused to the victim by the offence is to be compensated by the State Budget of Ukraine in cases and according to the procedure stipulated by law. However, the rule is of a declarative nature as, to date, no special law has been adopted. When the law will be adopted and how it will regulate the specificities of compensation of damage caused by enforced disappearance cannot be foreseen. Thus, the provision enshrined in Article 24 of Convention has not been implemented in the current legislation.

\section{CONCLUSIONS}

Therefore, the analysis of the current criminal procedural and civil law demonstrates that current provisions are not entirely appropriate to the specificities of investigation of enforced disappearance, and thus, issues of implementing provisions of Convention into domestic law will arise.

Consequently, there is a need for amendments and additions to the current criminal procedural law regarding the abovementioned issues and taking into account the specifics of criminal proceedings regarding enforced entrapment.

Given that enforced disappearance is considered to be the arrest, detention, abduction or any other form of deprivation of liberty by agents of the state including by a foreign one, followed by a refusal to acknowledge the deprivation of liberty or by concealment of the fate or whereabouts of the disappeared person, there is the need to clarify the jurisdiction and to 
stipulate that investigation of such facts shall be conducted only by investigators of State Bureau of Investigation.

It is inappropriate for cases of enforced disappearance to be limited in application of covert investigative (search) actions, except for collecting information from electronic information systems or parts thereof the access to which is not restricted by the system's owner, possessor or keeper or is not related to circumventing a system of logical protection and establishing the location of a radio electronic device (Article 146-1 Para. 1 of CC of Ukraine) and restriction to conduct covert investigative (search) actions (namely establishing the location of a radio electronic device (Article 268 Para. 4 of CCP of Ukraine); surveillance of an individual (Article 269 Para. 3 of CCP of Ukraine) prior to an investigative judge's ruling that requires revision, inter alia, of provision of $\mathrm{CC}$ of Ukraine in regard to the sanction of the article.

It is important to set the clear regulatory framework for access to the public or private custodial settings by investigators and prosecutors who provide procedural guidance in course of the investigation of offences provided for by Article 146-1 of CC of Ukraine.

Law of Ukraine 'On the legal status of missing persons' has to be amended regarding the possibility of initiation of search by bodies of the National Police of Ukraine without territorial linkage to 'appropriate local agency of the National Police of Ukraine'.

It is necessary to develop a regulatory and law-enforcement mechanism of realization of Article 1177 of Civil Code of Ukraine which provides that the damage caused to the victim by the offence is to be compensated by the State Budget of Ukraine in cases and according to the procedure stipulated by law.

It is required to clarify the grounds of using the mode of video conference and an interrogation using technical means from other premises, including outside the premises of court, or in other way making his identification impossible, and ensures parties to criminal proceedings the possibility to ask questions and hear answers thereto; when deciding on the application of safety measures to a victim during an interrogation in conditions making his identification impossible the test for finding violations of Article $6 \S 3$ (d) of ECHR developed by ECtHR in the case of 'AlKhawaja and Tahery v. the United Kingdom' should be applied.

\section{SUMMARY}

The article deals with criminal proceedings regarding enforced disappearance in Ukraine. The goal of the research is to identify issues of 
ensuring the provisions of Convention for the Protection of All Persons from Enforced Disappearance by procedural means of domestic legislation. The problems of pre-trial investigation and placement in public or private custodial settings, court proceedings and compensation for damage were discussed. The analysis of the current criminal procedural and civil law clearly demonstrates that current provisions are not entirely appropriate to the specificities of investigation of enforced disappearance, and thus, issues of implementing provisions of Convention for the Protection of All Persons from Enforced Disappearance into domestic law will arise. Consequently, there is a need for amendments and additions to the current criminal procedural law regarding abovementioned issues and taking into account the specifics of criminal proceedings regarding enforced entrapment. There is the need to clarify the jurisdiction and to stipulate that investigation of such facts shall be conducted only by investigators of State Bureau of Investigation. Also Law of Ukraine 'On the legal status of missing persons' has to be amended regarding the possibility of initiation of search by bodies of the National Police of Ukraine without territorial linkage to 'appropriate local agency of the National Police of Ukraine'; to clarify the grounds of using the mode of video conference and an interrogation using technical means from other premises, including outside the premises of court, or in other way making his identification impossible, and ensures parties to criminal proceedings the possibility to ask questions and hear answers thereto.

It is necessary to set the clear regulatory framework for access to the public or private custodial settings by investigators and prosecutors who provide procedural guidance in course of the investigation of offences provided for by Article 146-1 of CC of Ukraine; to develop a regulatory and law-enforcement mechanism of realization of Article 1177 of Civil Code of Ukraine which provides that the damage caused to the victim by the offence is to be compensated by the State Budget of Ukraine in cases and according to the procedure stipulated by law;.

\section{REFERENCES}

1. Babin B. (2019, February 24) Nasylnytski znyknennia v Ukraini. Pravovi deklaratsii ta realii viiny [Enforced disappearances in Ukraine. Legal declarations and realities of war]. Ukrainska Pravda. Retrieved from https://www.pravda.com.ua/columns/2019/02/24/7207525/ (accessed 16 October 2019).

2. Drozdov O., Drozdova O. (2016) Ohliad sprav shchodo inozemnykh krain, rozghlianutykh YeSPL protiahom bereznia 2016 roku [Review of the cases regarding foreign states decided by ECtHR during March 2016]. 
Visnyk Natsionalnoi asotsiatsii advokativ Ukrainy [Herald of Ukrainian Bar Association], vol. 24, no. 6, pp. 46-48.

3. Hloviuk I. V. (2013) Prezumptsii y tiahar dokazuvannia u rozghliadi slidchym suddeiu klopotan pro zastosuvannia zakhodiv zabezpechennia kryminalnoho provadzhennia [Presumptions and burden of proof in considering motions on application of measures to ensure criminal proceedings by an investigative judge]. Yurydychnyi chasopys Yurydychnyi chasopys Natsionalnoi akademii vnutrishnikh sprav [Legal herald of National academy of internal affairs], no. 2, pp. 84-89.

4. Hloviuk I. V. (2019) Rozsliduvannia faktiv znyknennia bezvisty (u konteksti torhivli liudmy) [Investigation of facts of disappearance (within the context of human trafficking)]. Proceedings of the Protydiia nezakonnii mihratsii ta torhivli liudmy: materialy III Mizhnarodnoho naukovopraktychnoho sympoziumu (Ukraine, Ivano-Frankivsk, April 12-13, 2019), Ivano-Frankivsk: Editorial and Publishing Department of King Danylo University, pp.31-34.

5. Khrystova H. Pro pozytyvni zoboviazannia derzhavy stosovno prav liudyny $\mathrm{v}$ umovakh zbroinoho konfliktu ta yoho naslidkiv [On positive obligations of the state regarding human rights in conditions of armed conflict and its consequences]. Retrieved from https://rm.coe.int/native/ $168072 \mathrm{~b} 3 \mathrm{cf}$ (accessed 16 October 2019).

6. Zavtur V. A. (2018) Prezumptsiia svobody osoby pry zastosuvanni punktu «S» statti 5 Konventsii pro zakhyst prav liudyny i osnovopolozhnykh svobod: praktyka Yevropeiskoho sudu z prav liudyny i natsionalnyi kontekst [Presumption of a person's freedom in application of Article 5 (c) of Convention for the Protection of Human Rights and Fundamental Freedom: case-law of European Court of Human Rights and domestic context]. Proceedings of the Praktyka Yevropeiskoho sudu z prav liudyny v diialnosti orhaniv prokuratury $i$ sudu: vyklyky ta perspektyvy : mater. I Mizhnar. nauk.-prakt. konf. (Ukraine, Kyiv, June 13, 2018), Kyiv: National Prosecution Academy of Ukraine, pp.81-85.

\section{Information about the author: Iryna Hloviuk,}

Doctor of Law, Associate Professor, Head of the Department of Criminal Procedure, National University "Odesa Law Academy”, 23, Fontanska road, Odesa, Ukraine ORCID ID: orcid.org/0000-0002-5685-3702 